The $5^{\text {th }}$ International Conference on Family Business and Entrepreneurship

\title{
TRANSGLOBAL LEADERSHIP INFLUENCE ON THE IMPLEMENTATION OF SUSTAINABLE PALM OIL INDUSTRY IN INDONESIA
}

\author{
Ramadhan Subakti ${ }^{1 *}$, Maria Jacinta Arquisola ${ }^{2}$ \\ ${ }^{1,2}$ Faculty of Business, President University, \\ Corresponding author:ramadhan.subakti@student.president.ac.id
}

\begin{abstract}
The company's lack of success in implementation the management of the palm oil industry based on Indonesian sustainable palm oil is thought to be due to a leadership crisis. The purpose of this study is to analyze the intelligence of transglobal leadership on the implementation of sustainable palm oil industry. The research approach used in this study is a quantitative method where data was collected susing a survey to collect primary data and open-ended interview questions to gain further clarity of the problems. Our respondents were 126 employees in the work unit of PTPN VIII who already have ISPO certification. Data analysis used Multiple Linear Regression. Data analysis used Multiple Linear Regression. The results of this study indicate that the intelligence of transglobal leadership has a significant positive effect on the implementation of sustainable palm oil industry. By emphasizing the aspects of business intelligence and global intelligence, it will be a solution in managing the sustainability of the palm oil industry.
\end{abstract}

Keywords: Transglobal Leadership, Implementation, ISPO.

\section{Introduction}

Palm oil has an important role in Indonesia's plantation crops. Industries that absorb a lot of palm oil derivatives are the fractionation/ refining industry, especially in the cooking oil, special fats, margarine, alchemical, and bath soap industries. Colchester et al. (2012) revealed that in cosmetics and household cleaners many are made from palm oil. In addition, the commodity of palm oil is support for non-oil and gas exports and a source of foreign exchange for the country in the agricultural sector. To strengthen the competitiveness of the Indonesian palm oil industry in international trade and carry out the commitment of the head of state to reduce the earth's problems especially climate change. The Ministry of Agriculture issued a policy, namely the Indonesian Sustainable Palm Oil (ISPO) standard. The ISPO standard has seven principles, these are (a) compliance with the legality of plantation business, (b) application of good plantation practices, (c) management of the environment, natural resources, and biodiversity (d) responsibility for the workforce, (e) social responsibility and economic empowerment of local communities, (f) implementing transparency (g) sustainable business development.

Data from the Indonesia Sustainable Palm Oil Secretariat stated that in March 2020 certified palm oil land reached 5.45 million hectares or $33.27 \%$ of the total oil palm area. The number of $33.27 \%$ certified is certainly an obstacle in meeting the sustainable development goals. The government issued this policy as the main instrument to improve public behavior, seeking solutions for public affairs that reflect domestic policy efforts with distributive, protective, competitive, and redistributive attributes (Muhammad et al., 2019). According to Afni et al. (2019) theoretically, the realm of public policy is within the scope of public administration, which has a vital and strategic role. Leadership plays a major role in the public administration processes. Leadership is an actor for the actualization of effective policies through the right decisions, time management, proper placement of resources, accommodating participation, and other 
principles that may appear in the good governance literature (Dendhart and Dendhart, 2007). On the other hand, failure to provide the right leadership results in a lack of efficiency in policy implementation, public service delivery, natural resource management (Muhammad et al., 2019).

The need for leadership in the palm oil plantation sector is very important. Furthermore, the problem of environmental impacts caused by the palm oil industry is often reflected in the community. In addition, the factory generates waste from the palm oil industry process so that the cost ofliving needs of the community increases in the form of replacement costs for clean water and medical expenses (Utami et al., 2017). Susanto et al. (2019) revealed that the largest waste produced was solid waste in the form of empty palm oil bunches, coir, mud, oil palm shells, and others. In 1 ton of palm oil, can to produce $6.5 \%$ palm shell waste, $4 \%$ palm mud, 13\% fiber, $23 \%$ empty palm oil bunches (Susanto et al., 2019). The results of research by Anwar et al (2016) in East Kalimantan show that the ability of plantation companies to meet ISPO standards has reached 79.14\%. Anwar et al (2016) further revealed that the determining factor for achieving the implementation of ISPO standards is the commitment of plantation companies as business actors who are supported by adequate human resources to realize sustainable plantation development and the role of the government as a regulator in overseeing the policies that have been set. Furthermore, research in different areas (Fuadah et al. 2018) revealed several shortcomings of PTPN VIII Cikasungka in managing plantations based on the first, second, and fourth principles of Indonesian sustainable palm oil.

Therefore, we need a leader with a new leadership style who can overcome these challenges, namely developing and maintaining palm oil in world trade, and turning it into a sustainable industry that will create better benefits for its employees, as well as maintain and maintain a healthy environment. Hendroyono's book Transglobal Leadership (2019) states that the existing types of transformational and transactional leadership styles are considered obsolete. The results of Sharkey et al. (2012) At the beginning of its development, these two leadership styles emerged in local forms that had not been able to reach global aspects. Therefore, Sharkey et al. (2012) initiated a broader and global leadership style, referred to as Transglobal leadership. Hermawati and Nasarudin (2016) then strengthen this understanding by mentioning the concept of Transglobal leadership reflects global principles. The influence of Transglobal leadership crosses cultural and national boundaries, is comprehensive, and makes a high contribution to the spirit of life to change human civilization (Sharkey et al., 2012). Kristianto (2009) revealed that the leadership quality possessed by a leader in an organization will determine the success of achieving a predetermined goal. The pattern of leadership in oil palm plantations and mills will be a role model if successful.

The basic concept of this paper aims to examine in depth the intelligence of Transglobal leadership in the oil palm plantation sector and identify implementation efforts to realize ISPO standards in work units owned by PT Perkebunan Nusantara VIII (PTPN VIII). It is hoped that palm oil industry companies that do not yet have standardization can use the results of this research as a reference for improving management based on the principles of Indonesia Sustainable Palm Oil and sustainable development goals with a Transglobal leadership intelligence approach.

\section{Literature Review}

\section{Transglobal Leadership}

Leadership is a management's ability to build, practice and lead a long-term vision of a company, as a vision regulator, motivator, analyzer, and mastery of work (Anderson and Rungtusanatham 1994; Luthans and Youssef 2007). Understanding an organization, the leadership of managers will affect the performance of each organizational work unit, after which it will automatically continue to affect the organization as a whole. (Pujiono, et al. 2020). According to Chen and Chen (2008) cited in Voon et al. (2011), previous studies on leadership have identified different types of leadership styles adopted by leaders in managing organizations. There are situational leadership styles by Kenneth Blanchard and Paul Hersey (1970), servant leadership by Robert Greenleaf (1977), then transactional and transformational leadership styles by Burns (1978), Implicit Leadership by Hanges, Braverman, and Reutsch (1991), Authentic leadership for the first time created by Dr. Bruce Avolio and Fred Luthans (2008), then there is Academic Leadership by Arquisola, Zutshi, Rentschler \& Billsberry (2020) and finally the Transglobal leadership style by Sharkey, L., Razi, N., Cooke, R., \& Barge, P. (2012).

Emphasized in their research that leadership plays a role in influencing individuals and collectives to achieve the desired goals. The transactional and transformational leadership styles proposed by Burns are the most popular among other leadership styles. Quoted from the book Transglobal Leadership by Bambang Hendroyono, James Macgregor Burns in 1978 initiated two types of leadership, namely transactional and transformational. However, Sharkey et al. (2012) revealed that transactional leadership only sees one 
transactional angle and transformational leadership between leaders and followers has not looked at global interests. Therefore, the concept of Transglobal leadership emerged which was initiated by Sharkey et al. (2012). Figure 6. shows the evolution of leadership theory described by Sharkey et al. (2012). All of these leadership models are processed and developed in the Western context, testing their suitability in the Asian context needs to be explored (Bush et al., 2018). This paper will examine the concept of Transglobal leadership in the palm oil industry sector in Indonesia.

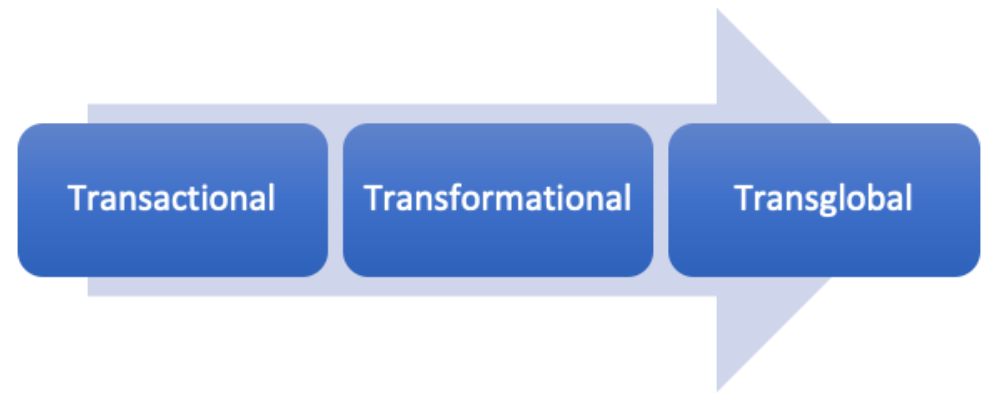

Figure 1. Evolution of Leadership Theory

(Source: Sharkey et al. (2012))

Sharkey et al. (2012) define six types of Transglobal leadership intelligence:

a. Cognitive intelligence, Intelligence Quotient of the peak level;

b. Moral intelligence, has ethical guidelines.

c. Emotional intelligence, be aware of the importance of the role of emotions, and have empathy.

d. Cultural intelligence, a leader puts forward the values of the customs of an area where he is located.

e. Business intelligence, understand processes, and adaptability of data.

f. Global intelligence, wherever he works, a leader must master the law and regulations, government, economics, and bureaucratic aspects.

The characteristics of a leader's intelligence are a determining factor in the success of adopting a Transglobal leadership style, carrying out fully or only partially applying these six main principles in some circumstances (Muhammad et al., 2017). In this study, only business intelligence and global intelligence were used as research variables. The two variables were selected based on the previous research by Muhammad et al. (2017) state that business intelligence and global intelligence have significant values, this is the basis for thinking in this study, raising only two intelligence variables.

\section{ISPO}

In addition to benefits, the Indonesian palm oil industry has several longstanding problems such as land tenure, social conflicts, and smallholders are the weakest actors in the value chain that need strong support from the government and other actors (Dina et. al. 2012). Regarding, to maintain the quality and quantity and maintain the power of palm oil in the international market, the government created a certification standard called ISPO (Imansari 2015). Indonesia's original sustainable palm oil regulations were made in 2011 and underwent a threefold renewal process until 2020. The evolution of Indonesia's sustainable palm oil principles is detailed in Table 1.

Indonesia's policy for implementing sustainable palm oil is mandatory for business actors. Furthermore, there are obstacles in achieving ISPO standards, including 1) the ability of available human resources to prepare documents and make programs related to Indonesian sustainable palm oil standards is still low; 2) the benefits of implementation of Indonesian sustainable palm oil are still not well understood and there are still doubts from the company management about the consistency of the government to oversee the policy. 3) There are still too many permits that must be fulfilled related to plantation management, and the lack of legal certainty regarding the status and land ownership of plantation companies (Anwar et al., 2016). The results of research by Anwar et al (2016) in East Kalimantan show that the ability of plantation companies to meet ISPO standards has reached 79.14\%. Anwar et al (2016) further revealed that the determining factor for achieving the implementation of ISPO standards is the commitment of plantation companies as business actors who are supported by adequate human resources, to realize sustainable plantation development and the role of the government as a regulator in overseeing the policies that have been set. Furthermore, research in different areas (Fuadah et al. 2018) revealed several shortcomings of PTPN VIII Cikasungka in managing plantations based on the first, second, and fourth principles of 
Indonesian sustainable palm oil.

Table 2. The Evolution of Indonesian Sustainable Palm Oil Principles

\begin{tabular}{|c|c|c|c|}
\hline \multirow{2}{*}{ Principles } & \multicolumn{3}{|c|}{ Minister of Agriculture Regulation (Permentan) } \\
\hline & Permentan 19/2011 & Permentan 11/2015 & Permentan 38/2020 \\
\hline 1. & $\begin{array}{l}\text { Licensing system and } \\
\text { plantation management. }\end{array}$ & Plantation business legality. & $\begin{array}{l}\text { Compliance with the legality of } \\
\text { plantation business. }\end{array}$ \\
\hline 2. & $\begin{array}{l}\text { Application of cultivation } \\
\text { technical guidelines and palm } \\
\text { oil processing. }\end{array}$ & Plantation management. & $\begin{array}{l}\text { Implementation of good } \\
\text { plantation practices. }\end{array}$ \\
\hline 3. & $\begin{array}{l}\text { Environmental management } \\
\text { and monitoring. }\end{array}$ & $\begin{array}{l}\text { Protection of the use of primary } \\
\text { natural forests and peatlands. }\end{array}$ & $\begin{array}{l}\text { Management of the } \\
\text { environment, natural resources, } \\
\text { and biodiversity. }\end{array}$ \\
\hline 4. & Responsibilities to workers. & $\begin{array}{l}\text { Environmental management } \\
\text { and monitoring. }\end{array}$ & $\begin{array}{l}\text { Responsibility for the } \\
\text { workforce }\end{array}$ \\
\hline 5. & $\begin{array}{l}\text { Social and community } \\
\text { responsibility. }\end{array}$ & Responsibilities to workers. & $\begin{array}{l}\text { Social responsibility and } \\
\text { economic empowerment of } \\
\text { local communities. }\end{array}$ \\
\hline 6. & $\begin{array}{l}\text { Community economic } \\
\text { empowerment }\end{array}$ & $\begin{array}{l}\text { Social responsibility and } \\
\text { community economic } \\
\text { empowerment. }\end{array}$ & Implementing transparency. \\
\hline 7. & $\begin{array}{l}\text { Sustainable business } \\
\text { development. }\end{array}$ & $\begin{array}{l}\text { Sustainable business } \\
\text { development. }\end{array}$ & $\begin{array}{l}\text { Sustainable business } \\
\text { development. }\end{array}$ \\
\hline
\end{tabular}

Sources: Directorate of Plantations of Ministry of Agriculture, 2020

\section{Hypothesis Statement}

The hypothesis of this study was built based on a literature review and previous research. These hypotheses are:

H1 : Business intelligence in transglobal leadership has a significant influence on the implementation of sustainable palm oil industry.

H2 : Global intelligence in transglobal leadership has a significant influence on the implementation of sustainable palm oil industry.

H3 : Business intelligence and global intelligence in transglobal leadership simultaneously have a significant influence on the implementation of sustainable palm oil industry.

\section{Research Model}

The research model is based on a systematic concept that describes the variables to be studied. Figure 2 . shows the research model in this study.

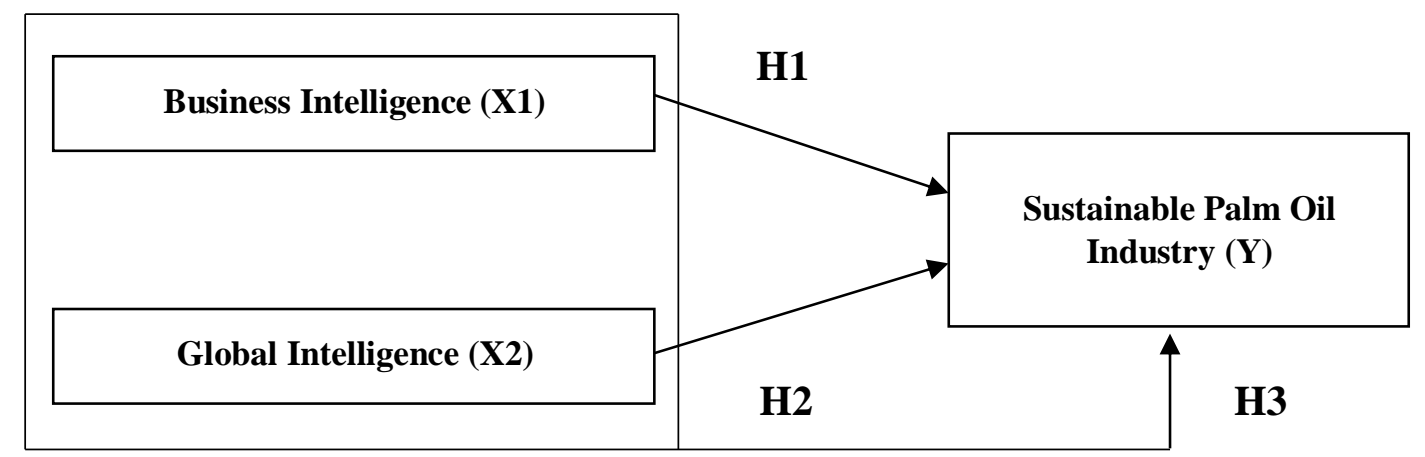

Figure 2. Research Model 


\section{Research Method}

The methods used in this research are quantitative methods and descriptive statistics. Primary data collection uses a questionnaire containing a statement of the main discussion based on the variables that have been compiled. The independent variable is Transglobal leadership with two supporting indicators, namely Business Intelligence (X1) and Global Intelligence (X2). The dependent variable is ISPO (Y). Our respondents were 126 employees in the work unit of PTPN VIII who already have ISPO certification taking into account the age above 21 years with upper-middle position, high school education, or equivalent with a minimum working period of 1 year. The questionnaire uses a Likert measurement scale. The data were processed using SPSS, analyzed, and further processed based on theory.

\section{Results and Discussion}

The results of the respondents in this study showed that the number of respondents consisted of $98.42 \%$ men and $1.58 \%$ women, this shows that oil palm plantation employees at PTPN VIII are dominated by men. The age of the majority of respondents in this study, aged 25-56 years as much as $98.4 \%$, indicates that employees are dominated by productive age with married status, and not a few employees are entering the age of the millennial generation. The validity test was calculated using SPSS by comparing the corrected item values for each question with $r$ tables. The $r$ count of the business intelligence variable table shows 0.1522 , the global intelligence $\mathrm{r}$ table variable value is 0.1509 , and the ISPO variable $\mathrm{r}$ table value is 0.1576 . The results of the validity test show that the value has a correlation coefficient of each variable above $0.1522,0.1509$, and 0.1576 . This means that all statement items are said to be valid. The reliability test of a variable construct is said to be reliable if it has a Cronbach's Alpha value $>0.70$. The results of the reliability test for each of the above variables are $0.834,0.812$, and 0.844 . This shows that each variable in this study is said to be reliable. Table 2 will explain further about Partial Test Result.

Table 2. Partial Test Result

\begin{tabular}{|c|c|c|c|c|c|c|c|c|}
\hline & \multirow{2}{*}{ Model } & \multicolumn{2}{|c|}{$\begin{array}{l}\text { Unstandardized } \\
\text { Coefficients }\end{array}$} & \multirow{2}{*}{$\begin{array}{c}\text { Standardized } \\
\text { Coefficients } \\
\text { Beta }\end{array}$} & \multirow{2}{*}{$\mathrm{t}$} & \multirow{2}{*}{ Sig. } & \multicolumn{2}{|c|}{$\begin{array}{c}\text { Collinearity } \\
\text { Statistics }\end{array}$} \\
\hline & & B & $\begin{array}{l}\text { Std. } \\
\text { Error }\end{array}$ & & & & $\begin{array}{c}\text { Tolera } \\
\text { nce }\end{array}$ & VIF \\
\hline 1 & (Constant) & 29.682 & 4.541 & & $\begin{array}{r}6.5 \\
37\end{array}$ & .000 & & \\
\hline & $\begin{array}{l}\mathrm{X} 1=\text { Business } \\
\text { Intelligence }\end{array}$ & .684 & .133 & .440 & $\begin{array}{r}5.1 \\
31\end{array}$ & .000 & .610 & $\begin{array}{r}1.64 \\
0\end{array}$ \\
\hline & $\begin{array}{l}\text { X2 = Global } \\
\text { Intelligence }\end{array}$ & .527 & .150 & .301 & $\begin{array}{r}3.5 \\
08\end{array}$ & .001 & .610 & $\begin{array}{r}1.64 \\
0\end{array}$ \\
\hline
\end{tabular}

Source: Primary data by researchers

Based on table above, it can be seen that the $t_{\text {count }}$ of each variable is as follows:

Business Intelligence (X1) influences the implementation of sustainable palm oil industry (Y).

$\mathrm{H}_{0}: \beta_{1}=0$, business intelligence does not have a significant influence on the implementation of sustainable palm oil industry.

$\mathrm{H}_{1}: \beta_{1} \neq 0$, business intelligence has a significant influence on the implementation of sustainable palm oil industry.

Based on Partial Test be obtained a $t_{\text {count }}$ value of 5.131 with a Sig value of 0.000 and a table value of 1.657. This shows that $t_{\text {count }}>t_{\text {table }}$ thus $H_{0}$ is rejected and $H_{1} d$ is accepted, meaning that Business Intelligence (X1) influences the implementation of sustainable palm oil industry (Y).

Global Intelligence (X2) influences the implementation of sustainable palm oil industry (Y).

$\mathrm{H}_{0}: \beta_{2}=0$, global intelligence does not have a significant influence on the implementation of sustainable palm oil industry.

$\mathrm{H}_{1}: \beta_{2} \neq 0$, global intelligence has a significant influence on the implementation of sustainable palm oil industry.

Based on Partial Test can be obtained a $t_{\text {count }}$ value of 3.508 with a Sig value of 0.001 and a $t_{\text {table }}$ value of 1.657. This shows that $t_{\text {count }}>t_{\text {table }}$ thus $\mathrm{H}_{0}$ is rejected and $\mathrm{H}_{1} \mathrm{~d}$ is accepted, meaning that Global Intelligence (X2) influences the implementation of sustainable palm oil industry (Y). Simultaneously test that the variables of Business Intelligence and Global Intelligence simultaneously have a significant influence on the ISPO Standard variable. Because the $F_{\text {count }}$ score of 50.133 is greater than $F_{\text {table }}$ of 3.07. Table 3 will explain further about Simultaneously Test Result. 
Table 3. Simultaneously Test Result

\begin{tabular}{cccccc}
\hline Model & Sum of Squares & Df & Mean Square & F & Sig. \\
\hline Regression & 2236.436 & 2 & 1118.218 & 50.133 & $.000^{\mathrm{b}}$ \\
Residual & 2743.532 & 123 & 22.305 & & \\
Total & 4979.968 & 125 & & & \\
\hline
\end{tabular}

Source: Primary data by researchers

Based on research data processing, the two dimensions of transglobal leadership intelligence studied have a significant effect on the implementation of sustainable palm oil industry. This means that the better the role of the leader, the more the goals of sustainable palm oil industry in Indonesia are improved. This learning can be applied by leaders to invite or urging all subordinates to serve in achieving organizational goals under the abilities of subordinates (George and Terry 2011). The above hypothesis testing also aims to determine the direct influence of business intelligence and global intelligence on the implementation of ISPO standards. Meaning that to determine the influence of the intelligence of oil palm company leaders on the implementation of ISPO standards, it can be seen from the results of achievements in completing ISPO documents and sustainability activities in the field. This finding strengthens the description by Sharkey et al. (2012) that during the crisis that has occurred shows the need for leadership and intelligence aspects, especially after the discovery of brain function. So that in carrying out their duties as a leader they can run well.

The variables of business intelligence and global intelligence have different average scores of 4.15 and 3.19 , thus a company leader must have the business intelligence and global intelligence in plantation management based on Indonesia Sustainable Palm Oil. This indicates that the leadership at PTPN VIII has also succeeded in creating sustainable palm oil industry action, then good relationships are established between employees and superiors in business, this can be seen from every day in the morning each office division provides time to inform what to do next and job evaluation. These results are in line with the statement of Kreitner and Kinicki (2014) that in inviting subordinates or HR a leader must go through continuous activities so that they can influence the behavior of others as desired to achieve organizational or company goals. Acceptance of this hypothesis strengthens the theory of Transglobal leadership styles initiated by Sharkey et al (2012), than previous research on intelligence by Muhammad et al. (2019). Lastly, Geoghegan and Dulewicz (2008) on leadership competencies contribute to project success. The achievement of ISPO implementation by PTPN VIII to date is the impact of changes brought about by increasing education provided to employees to strengthen PTPN VIII dealing with ongoing problems in the palm oil industry. Because strong leadership will bring changes in the level of office \& factory management, processing processes, company organizational culture to the level of better individual employees.

\section{Conclusion and Implications}

Leaders in each dimension of the company's organization adopt different leadership styles in addressing the sustainable management of the palm oil industry. Transglobal leadership has become a renewal and extension of transactional and transformational leadership styles. Furthermore, in the palm oil sector, transglobal leadership by emphasizing the aspects of business intelligence and global intelligence will be a solution in managing the sustainable palm oil industry. This affirmation is conveyed because, this study located at PTPN VIII, it shows that Transglobal leadership has a positive significant value.

The implications that can be carried out by companies in the palm oil sector, both those that have and do not have ISPO certification standards through the indicators approach that affect PTPN VIII in this study, are: (1) in achieving sustainable development goals, the leaders of the palm oil industry companies must adopt a transglobal leadership style, especially in business intelligence and global intelligence, (2) increase the capacity of human resources in the company to understand well the benefits of implementing a sustainable palm oil industry for the environment and the community so that the ISPO document implementation process runs effectively. We hope that the company through the following steps can improve the sustainable palm oil industry in Indonesia. We also suggest promoting research on transglobal leadership in other sectors in particular.

\section{References}

Afni, Z., Suryadi, S., Azis, Y.M.A., \& Purwanto B.H. (2019). The Role of Transglobal Leadership for Forest and Land Fire Control in Riau Province. International Journal of Innovation, Creativity and Change. Vol 9 (5).

Anderson JC., \& Rungtusanatham M. (1994). A Theory Of Quality Management Underlying The Deming 
Management Method. J Acad Manag Rev. 19:472-509.

Anwar, R., Sitorus S.R.P., Fauzi, A.M., Widiatmaka, \& Machfud. (2016). Achievement Of Indonesian Sustainable Palm Oil Standards Of Pacm Oil Plantation Management In East Borneo Indonesia. Jurnal Littri vol 22 (1) 11-18.

Arquisola, M.J., Zutshi, A., Rentschler, R., \& Billsberry, J. (2020). Academic leaders' double bind: challenges from an Indonesian perspective". International Journal of Educational Management. Vol. 34 No. 2, pp. 397-416.

Bass, B.M., \& Avolio, B.J. (1994). The Implication of Transaction and Transformational Leadership for Individual, Team, and Organizational Development, Research in Organizational Change and Development. 4, 231-272.

Bush, T., Abdul Hamid, S., Ng, A., \& Kaparou, M. (2018). School leadership theories and the Malaysia Education Blueprint: Findings from a systematic literature review. International Journal of Educational Management, Vol. 32 No. 7, pp. 1245-1265.

Chen, K. J., \& Chen, S. I. (2008). Personal traits and leadership styles of Taiwan's higher educational institution in innovative operations. Journal of American Academy of Business, Cambridge, Vol. 12, No. 2, pp. 145-150.

Colchester, M., Chao, S., Dallinger, J., Sokhannaro, H.E.P., Thai, V., \& Villanueva, Jo. (2011). Ekspansi Kelapa Sawit di Asia Tenggara: Kecenderungan dan Implikasi bagi Masyarakat lokal dan Masyarakat Adat. Moreton in Marsh: Forest Peoples Programme.

Dina, H., Chozin, M.A., Fauzi A.M. (2012). Analysis on Indonesian Sustainable Palm Oil (ISPO): A Qualitative Assessment on the Success Factors for ISPO. Jurnal Manajemen \& Agribisnis. 9(1): 39-48.

Denhardt, J. V., \& Denhardt, R. B. (2007). The New Public Service: Serving, not Steering. M.E. Sharpe, Inc. England.

Directorate of Plantations of Ministry of Agriculture. (2020). Palm Oil Production by Province in Indonesia. 2016-2020. Jakarta: Kementan.

Faudah, D.T. (2018). Pengelolaan Perkebunan Kelapa Sawit Berdasarkan Prinsip ISPO di PTPN VIII Cikasungka, Jawa Barat. Jurnal Ilmu Pertanian Indonesia (JIPI), Desember Vol. 23 (3): 190-195.

George M., \& Terry R. (2011). POAC (Planning, Organizing, Actuating, Controlling) Management in company aspect. Jilid 2. Bandung: PT Rafika Aditama

Geoghegan, L., \& Dulewicz, V. (2008). Do Project Managers' Leadership Competencies Contribute to Project Success? Project Management Journal.

Hersey, Paul., \& Kenneth H. Blanchard. 1990. Manajemen Perilaku Organisasi: Pendayagunaan Sumber Daya Manusia. 69. 182-183.

Hendroyono, B. (2019). Kepemimpinan Transglobal Kunci Sukses Pembangunan Kehuatanan Masa Depan.

Hermawati, A., \& Nasharuddin, M. (2016). Trans global leadership, quality of work life, and employee performance in cooperatives in East Java, Indonesia. International Journal of Business Manajement, Vol. 1 No. 1, pp. 1-8.

Imansari, S.Y. (2015). Penetapan Kebijakan Indonesian Sustainable Palm Oil Pada Tahun 2011. Jember: Universitas Jember.

Kreitner R., \& Kinicki A. (2014). Perilaku Organisasi. Journal Organizational Behavior.

Kristianto, D. (2009). Komitmen Organisasi, Model Kepemimpinan Manajerial Dan Pengaruhnya Terhadap Kinerja. J Ekon dan Kewirausahaan. 9:45-52.

Luthans, F., \& Youssef C.M. (2007). Emerging Positive Organizational Behavior. J Manage. 33:321-349.

Muhammad, F., Hendroyono, B., Supriyono B., \& Wijaya, A.F. (2016). The Influence of the Intelligence of Transglobal Leadership on Good Governance-Based Forest Management. International Journal of Administrative Science \& Organization. September Vol 23 (3).

Pujiono, B., Setiawan, M., Sumiati and Wijayanti R. (2020). The effect of transglobal leadership and organizational culture on job performance - Inter-employee trust as Moderating Variable. International Journal of Public Leadership Vol. 16 No. 3, 2020 pp. 319-335.

Sharkey, L., Razi, N., Cooke, R., \& Barge, P. (2012). Winning with Transglobal Leadership. New York: McGrawHill.

Susanto, I.T., \& Anggraini, S.P.A. (2019). Pra Rancang Bangun Pabrik Pupuk Biochar Dari Tandan Kosong Kelapa Sawit Dengan Kapasitas 11.000 Ton/Tahun Menggunakan Alat Utama Rotary Kiln. eUREKA: Jurnal Penelitian Teknik Sipil dan Teknik Kimia, 3(2): 245-250.

Utami, R., Putri, E.I.K., \& Ekayani, M. (2017). Economy and Environmental Impact of Oil Palm Palm 
Plantation Expansion (Case Study: Panyabungan Village, Merlung Sub-District, West Tanjung Jabung Barat District, Jambi). JIPI. Vol. 22 (2): 115-126.

Voon, M.L., Lo, M.C., Ngui, K.S., \& Ayob, N.B., (2011). The influence of leadership styles on employees' job satisfaction in public sector organizations in Malaysia. International Journal of Business, Management and Social Sciences Vol. 2, No. 1, 2011, pp. 24-32. 